Pak. j. sci. ind. res. Ser. A: phys. sci. 2020 63A(3) 153-161

\title{
Eco-Friendly Degradation of Blue Reactive Dye Enriched Textile Water by Floating Treatment Wetlands (FTWs) System (Part A)
}

\author{
${ }^{a}$ Muhammad Qamar Tusief ${ }^{\text {a*, Mumtaz Hasan Malik }}{ }^{\mathrm{b}}$, Muhammad Mohsin ${ }^{\mathrm{c}}$ \\ and Hafiz Naeem Asghar ${ }^{\text {, }}$ \\ ${ }^{a}$ Department of Fibre and Textile Technology, University of Agriculture, Faisalabad, Pakistan \\ ${ }^{b}$ School of Textile and Design, University of Management and Technology Lahore, Pakistan \\ ${ }^{\mathrm{c}}$ Department of Textile Engineering, University of Engineering and Technology Lahore \\ (Faisalabad Campus), Pakistan \\ ${ }^{\mathrm{d} I n s t i t u t e}$ of Soil and Environmental Sciences, University of Agriculture Faisalabad. Pakistan
}

(received December 19, 2018; revised September 2, 2019; accepted September 6, 2019)

\begin{abstract}
Enriched effluents of textile dye are considered highly complex and containing hazardous components. Their discharge to nearby drains without treatment has high risk to environmental and human health. The physico-chemical strategies under practice to treat these effluents have technical and economical restrictions. Comparatively, biological treatment methods like floating treatment wetlands are less expensive and eco-friendly. Blue reactive dye enriched textile water and prepared synthetically and added to an artificial Floating Treatment Wetlands (FTWs) system vegetated with Eichhornia crassipes and Pistia stratiotes aquatic plants along with Bacillus cereus and Bacillus subtilis bacterial strains. Plant-microbe synergistic effect was studied by measuring the physico-chemical parameters i.e. $\mathrm{pH}$, EC, TDS and TSS of dye enriched water after 0 (at the start of the experiment), 24, 48 and $72 \mathrm{~h}$ retention time. A substantial decrease in all these factors $(11.34 \%, 40.67 \%, 64.37 \%, 58.23 \%$, for $\mathrm{pH}, \mathrm{EC}$, TDS and TSS respectively) was noted for E. crassipes and B. cereus combination after $72 \mathrm{~h}$ retention time. This high lighted the fact that plant assisted microbial FTWs technique can be a unique approach to remediate the textile effluents.
\end{abstract}

Keywords: textile wastewater treatment, blue reactive dyes, floating treatment wetlands (FTWs), plantmicrobe interaction

\section{Introduction}

Availability of fresh water has become a serious issue of this age. The pollution of water bodies is a burning issue of this age all over the universe. It is more serious in developing countries. Among all contributors, textile industry has its major share to pollute water in these countries due to the availability of cheap labour and less strict waste disposal norms (Valaria et al., 2011). The wastewater generated from industrial sector especially from textile dyeing industry has been considered as most perilous in terms of its volume and composition (Wang et al., 2017). In open market about more than 100,000 dyes have been documented as commercially available and the annual production of dyestuff has been reported about 700,000 tons (Mishra and Maiti, 2018). Among these, reactive dyes are most commonly used in dyeing processes especially for cotton product dyeing industry (Sudha et al., 2014). In all available dyeing mechanisms, it has been recognized approximately more than $15 \%$ dye stuff remains unfixed

*Author for correspondence; E-mail: taimurjf@yahoo.com worldwide annually (Prasad and Aikat, 2014). This loss has been accepted because of the occurrence of unreactive hydrolyzed dyes in dye bath. This hydrolysis of dyes happens due to its reaction with water molecules in dye solution (Patil et al., 2010). During washing this unfixed dye is removed from the fabric, becoming part of the wastewater. Many pre-dyeing and post dyeing processes like scouring, bleaching, finishing, washing etc. have been acknowledged to contribute different kinds of pollutants like detergents, bleaching agents, caustic, acids and salts in water (Hussein and Scholz, 2018; Ozturk et al., 2015). When this highly contaminated water enters in nearby drains without treatment then it causes severe environmental and aquatic pollution (Ayed et al., 2017a). Mutagenicity, allergic reactions, carcinogenicity and acute cytotoxicity of textile dyes on fishes, crop plants, rats, mollusks, human being and cultured mammalian cells are well documented evidences of hazardous effects of these dye enriched effluents (Khandare et al., 2016) and when these effluents are leached into the ground, the ground water gets contaminated also. In dyeing industry 
especially in Pakistan (a major cotton producing country) cotton products are most widely processed and reactive dyes are commonly used. These dyes have been considered as having bright colors, easy application techniques and less energy consumption (Andrade et al., 2007). Among these dyes, blue is one of the most commonly used primary reactive dyes. Blue dye has been observed as highly resistant to chemical oxidation and its aromatic anthraquinone structure makes it difficult to break down (Fig. 1), modified from Song et al. (2008).

Different physical, chemical and biological techniques like stabilization, coagulation, ion exchange, chemical oxidation, membrane filtration, adsorption etc. have been applied to degrade textile effluents (Chen et al., 2009; Aslam et al., 2004). But all these techniques have been reported to have limitations in respect of high cost, operation skill, regular maintenance and generation of high quantity of secondary waste like sludge that require further safe disposal (Sala and Gutierrez-Bouzan, 2012; Mohd Salleh et al., 2011).

In contrast to all above drawbacks of conventional methods used for textile wastewater treatment, plant based treatment techniques also known as "Phytoremediation" have been approved as an effective way to treat wastewater (Khandare et al., 2013). Phytoremediation has been recognized as operationally simple, economical, eco-friendly and natural way to treat contaminated water (Choo et al., 2006). In addition to plants, bacterial treatment of textile waste water has also been reported as an effective way (Kabra et al., 2013) because bacteria have capability to grow in short time and have direct interaction with dye molecules that enhance degradation process (Kalyani et al, 2009). It has been accredited that the bacteria produce various

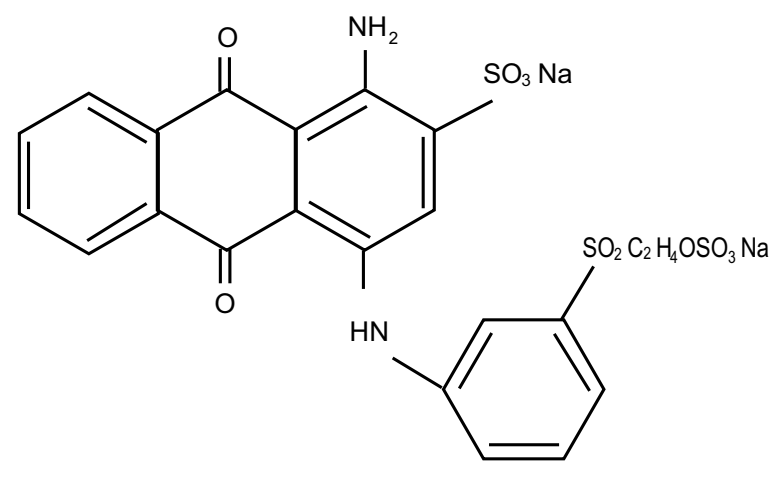

Fig. 1. Chemical structure of reactive blue. enzymes of oxidative-reductive type like laccase, azoreductase, peroxidase, which enhance the mineralization and effective degradation of many reactive dyes (Bedekar et al., 2014). However, the selection of dynamic bacterial species in order to achieve effective dye degradation is of supreme importance. Many studies have been reported in this respect such as Chang et al., (2001) who observed $90 \%$ colour degradation of 300 $\mathrm{mg} / \mathrm{L}$ reactive red-22 dye for $20 \mathrm{~h}$ incubation time by Pseudomonas luteola in static condition. In the same line Maqbool et al. (2016) made research study on mixed dye solution and concluded a simultaneous removal of $100 \mathrm{mg} / \mathrm{L}$ of these mixed reactive dyes (reactive black-5, reactive red-120, reactive orange-16 and reactive yellow-2) by Pseudomonas aeruginosa ZM130 after $180 \mathrm{~h}$ incubation time in static conditions. Many other works like Gulati and Jha (2014) investigated on klebsiella sp. BI-11, isolated from soil, to degrade reactive blue-19 $(100 \mathrm{mg} / \mathrm{L})$ and found $95 \%$ removal of dye, Shah (2014) made study on Pseudomonas sp for de-colourization of reactive black $(100 \mathrm{mg} / \mathrm{L})$ and noted up to $95 \%$ dye removal, Ayed et al. $(2017 \mathrm{a}, \mathrm{b})$ explored Staphylococcus aureus consortium for degradation of reactive violet-5 dye $1000 \mathrm{mg} / \mathrm{L}$ ) and observed $99 \%$ removal of dye. In the light of available literature it has been disclosed that bacterium or bacterial consortium use would be a nice choice for reactive dye degradation from contaminated wastewater. Bacillus subtilis and Bacillus cereus bacteria belong to Bacillus species that have been renowned to degrade organic pollutants along with to promote plant growth by producing plant hormones like indole acetic acid $\left(\mathrm{C}_{10} \mathrm{H}_{9} \mathrm{NO}_{2}\right)$ and phosphorus solublization (Asghar et al., 2017; Zaidi et al., 2006).

Plant microbial assisted technique is an emergent way that has been recognized as more proficient tool to cleanse contaminated water and having in situ applicability (Anuprita et al., 2015). In this system plants take up nutrients from contaminated source and their nutrients up taking ability get stimulation by microbial communities (Afzal et al., 2014; Shehzadi et al., 2014). Plants provide habitat for microbes and their roots and shoots promote microbial activity.

Constructed wetlands have been measured as reliable plant based wastewater treatment techniques (Vymazal., 2011). Floating treatment wetlands (FTWs) are one of them. FTWs have been considered as the integration of agronomy and ecological engineering and a novel approach to detoxify textile dye enriched effluents. In 
this system aquatic plants remain floating on surface of contaminated water, while their roots hang freely in the water (Hwang and LePage, 2011). FTWs system has been agreed upon to treat the polluted water by physical, biological and chemical ways (Chang et al., 2013). It has been explored that physically plants create hindrance in water flow and reduce its velocity resulting better situation for sedimentation of dissolved and suspended solids; biologically plants do photosynthesis, respiration, phyto-extraction, rihizodegradation, while chemically the contaminants are killed by plant roots due to their generation of antibiotic material (Arshad et al, 2017). Plant selection for this technology is of utmost importance. The plants that have dense root system are most commonly used in floating wetland technologies. The contaminant removal efficiency and the oxygen generation of the floating wetland have been observed to increase with the vegetation of the plant in the wetland (Li et al., 2010).

E. crassipes (water hyacinth) is an aquatic plant having broad, thick leaves and can rise about $1 \mathrm{~m}$ above the water surface. Its roots and shoot system is very dense and have been reported to be supportive for wastewater treatment (Mishra and Maiti, 2018; Saha et al., 2017). Similarly P. stratiotes (water lettuce) is a free floating aquatic plant that doubles its biomass in 6 days. It has been observed very effective to treat contaminated water applying FTWs technique (Arshad et al., 2017; Pawan et al., 2015). FTWs system has been accepted as a highly operative technique to remediate different types of wastewater (Lynch et al., 2015). However, rare work is available on plant-bacteria assisted FTWs technology for desalination and decolorization of reactive blue dye enriched textile wastewater with respect to hydraulic retention time (average length of time for which solution remained in bioreactor). So, this study was planned to assess the potential of aquatic plants (E. crassipes and P. stratiotes) and bacteria (B. cereus and B. subtilis), in synergy, to treat the reactive blue dye enriched textile effluents under the umbrella of FTWs technology.

\section{Materials and Methods}

FTWs system was designed in transparent polyethylene containers ( $39 \mathrm{~cm}$ x $28 \mathrm{~cm}$ x $20 \mathrm{~cm}$ ) of 10 liter capacity having synthetically prepared reactive Blue dye enriched solution vegetated with $E$. crassipes and $P$. stratiotes aquatic plants (Fig. 2). Two bacteria, "B. cereus" and "B. subtilis" that have been acknowledged for their capability to degrade contaminants in wastewater

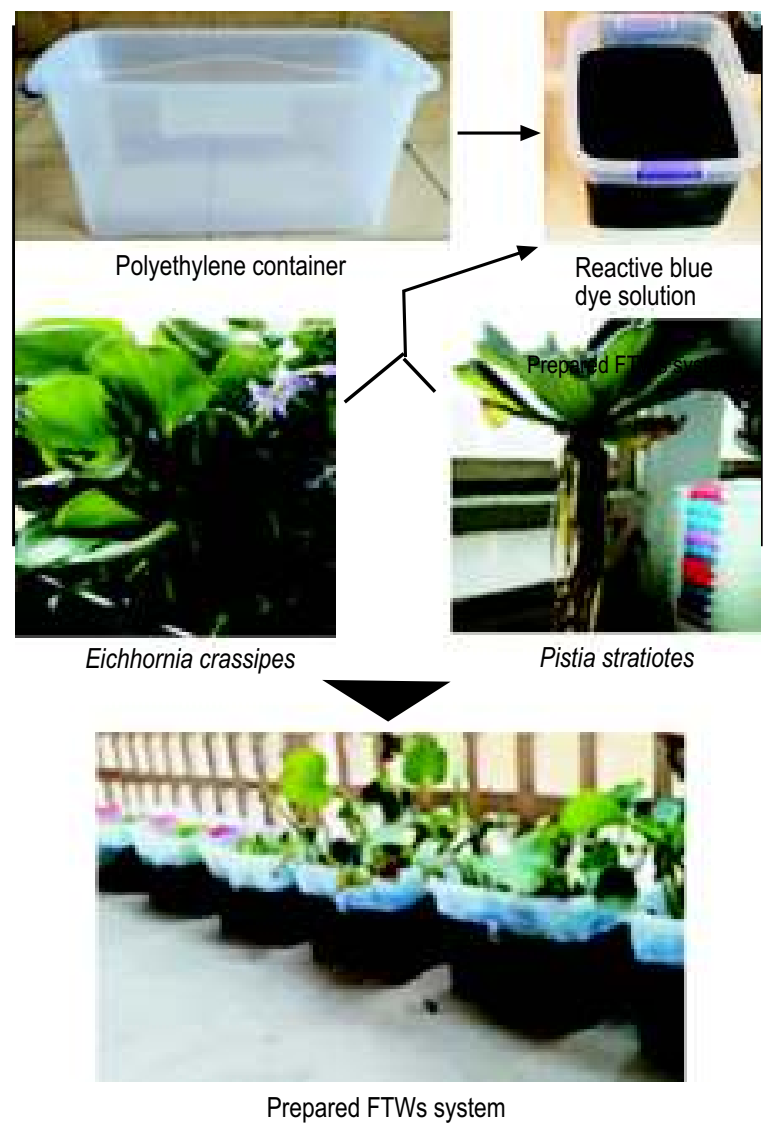

Fig. 2. Various components and designing of FTWs system.

(Asghar et al., 2017; Nair and Swarnalatha, 2015), were also pooled with these plants to develop plantbacteria synergism in order to treat textile effluents. The interaction of these bacteria with plants was made by dipping plants in $500 \mathrm{~mL}$ broth of each bacterium for $40 \mathrm{~min}$. Then these plants were transferred to each treatment reactor according to their decided number.

Different aspects of experimental study have been explained below.

Reactive blue dye enriched solution preparation. Reactive blue dye enriched textile wastewater solution of $0.1 \%$ shade depth was prepared synthetically at lab scale according to the following recipe.

Dye $=1 \mathrm{~g} / \mathrm{L} ;$ Glauber's salt $=5 \mathrm{~g} / \mathrm{L}$; Soda ash $=0.4 \mathrm{~g} / \mathrm{L}$ (at fixed $8.91 \mathrm{pH}$ )

Collection of effluent degrading bacterial strains. Pre-isolated and characterized pollutant degrading bacteria "B. cereus" and "B. subtilis" were taken from Soil Microbiology and Biochemistry Lab of Institute 
Table 1. Parameters and their values selected for the current study

\begin{tabular}{|c|c|c|c|c|}
\hline Textile effluent source & Retention time (h) & Bacterial strains & Plant types & Reactors description \\
\hline Reactive blue & $\begin{array}{l}\mathrm{TM} 1=0 \\
\mathrm{TM} 2=24 \\
\mathrm{TM} 3=48 \\
\mathrm{TM} 4=72\end{array}$ & $\begin{array}{l}\text { Bacillus cereus } \\
\text { Bacillus subtilis }\end{array}$ & $\begin{array}{l}\text { Eichhornia crassipes } \\
\text { Pistia stratiotes }\end{array}$ & $\begin{array}{l}\mathrm{R} 1=\text { effluent }+ \text { plant } \\
\mathrm{R} 2=\text { effluent }+ \text { bacteria } \\
\mathrm{R} 3=\text { effluent }+ \text { plant }+ \text { bacteria }\end{array}$ \\
\hline
\end{tabular}

of Soil and Environmental Sciences, University of Agriculture Faisalabad, Pakistan. The efficacy of these bacteria regarding pollutant degradation and plant growth promotion had been already testified (Rafique, 2015).

Plants selection. Native plants for such treatments are suitable due to their ability to get immunity with the local climatic conditions. So, locally available aquatic plants, E. crassipes and P. stratiotes, were selected for the present research study. These plants exist in abundance in many fresh and waste water bodies located in the surroundings of Lahore and Faisalabad (Hub of textile industry), Pakistan. Fully grown plants were collected and stored in water tubs of circular shape having $76 \mathrm{~cm}$ diameter and $30 \mathrm{~cm}$ depth under ambient conditions $\left(28-43{ }^{\circ} \mathrm{C}\right.$ temperature and $35-50 \%$ humidity). For making them to survive in pure textile water they were immune by giving them textile wastewater collecting from Paharrung drain, Faisalabad, near the out let of Kalash textile dyeing and processing mill, for one week with increasing ratio of tap water and textile water i.e. 0:100, 20:80, 40:60, 60:40, 80:20 and 100:0. After getting immunity the plants flourished well in pure textile water and increased their population about in double within 10 days. Then they were transferred to containers having synthetically prepared reactive blue dye enriched effluent in order to develop FTWs reactors. Five plants of nearly equal mass were vegetated in each FTWs experimental reactor. The worth of collected bacterial strain and plants was tested for degrading textile wastewater at lab scale. Various operational parameters like hydraulic retention time, bacterial strains, plants types and their interaction were analyzed for getting their optimum levels. These factors were selected in the range as given in Table 1.

Designing of FTWs experimental reactors. Eight experimental FTWs treatment reactors were designed with the following specifications.

$\mathrm{C}=$ control (only reactive blue dye enriched effluent); $\mathrm{T} 1$ = blue dye effluent + Eichhornia crassipes plant; $\mathrm{T} 2=$ blue dye effluent + Eichhornia crassipes + Bacillus cereus; $\mathrm{T} 3=$ blue dye effluent + Eichhornia crassipes + Bacillus subtilis; T4 = blue dye effluent + Pistia stratiotes plant; T5 = blue dye effluent + Pistia stratiotes + Bacillus cereus; T6 = blue dye effluent + Pistia stratiotes + Bacillus subtilis; $77=$ blue dye effluent + Bacillus cereus; $\mathrm{T} 8=$ blue dye effluent + Bacillus subtilis

\section{Sample collection.}

Samples were collected in plastic bottles thoroughly washed with detergent (prepared by adding $1 \mathrm{~L}$ of concentrated $\mathrm{H}_{2} \mathrm{SO}_{4}$ by stirring with $35 \mathrm{~mL}$ saturated sodium dichromate solution) then rinsed comprehensively with tap water. Finally, bottles were rinsed with distilled water before adding sample and stored in refrigerator at about $4{ }^{\circ} \mathrm{C}$ for $24 \mathrm{~h}$ before analysis.

Testing of textile effluent. $500 \mathrm{~mL}$ sample was taken from each reactor after each selected retention time and analysed for determining the $\mathrm{pH}, \mathrm{EC}$, TDS and TSS according to standard procedures (APHA, 2005). $\mathrm{pH}$ was measured by ML. $1010 \mathrm{pH}$ meter of HANNA instruments after calibrating it with 4 and $9 \mathrm{pH}$ buffer solutions, while EC and TDS were measured by CO150 conductivity meter of $\mathrm{HACH}$ after proper calibration, while TSS was measured by filtration method using 1.2 $\mu \mathrm{m}$ pore size filter.

Statistical analysis. All the selected water quality parameters were statistically analyzed in order to check the overall significance of data. The difference between treatment means was compared by employing the least significant difference (LSD) test. Complete randomized design (CRD) was applied to arrange this experiment. Moreover, the effect of time on selected parameters was analyzed by using regression analysis. The statistical tests were conducted by operating the SAS program version STAT 9.1 of SAS Institute (Clark, 2004).

\section{Results and Discussion}

Physico-chemical properties of reactive blue dye enriched textile water. Effect of various treatments and hydraulic retention time on $\mathrm{pH}$ value of reactive blue dye enriched textile water. There was found 
significant impact of all selected treatments and retention time on $\mathrm{pH}$ value of the water under treatment. The maximum value of $\mathrm{pH}$ (8.91) was noted for control treatment (C) i.e. at the start of the experiment (TM1= retention time of 0 hour). This reduced to 7.90 after 72 hours retention time (TM4) under combined treatment of water with E.crassipes plant and B.cereus bacteria. This treatment combination made $11.34 \%$ reduction in $\mathrm{pH}$ of blue dye enriched wastewater with maximum retention time as shown in Fig. 3. These findings disclosed that with the increase of time, E. crassipes and $B$. cereus synergistic treatment reduced the $\mathrm{pH}$ of the solution significantly.

This $\mathrm{pH}$ reduction might be credited to the production of carbon dioxide by plants through their photosynthesis process. Moreover, the presence of bacteria in the system has been reported to degrade organic pollutants in wastewater that resulted in the formation of organic acids like formic and acetic acids etc (Somasiri et al., 2008).

\section{Effect of various treatments and hydraulic retention} time on EC value of reactive blue dye enriched textile water. The EC value of blue dye enriched solution was influenced significantly by all selected treatments and retention times. The value of EC of solution was noted highest $(9.91 \mathrm{dS} / \mathrm{m})$ for control treatment $(\mathrm{C})$ at the initial stage of experiment i.e. (TM4 $=0$ hour retention time). There was observed prominent reduction in EC up to value of $5.88 \mathrm{dS} / \mathrm{m}$ after $72 \mathrm{~h}$ retention time for $E$. crassipes plant treatment in synergy with $B$. cereus bacteria. A considerable reduction (40.67\%) was noticed

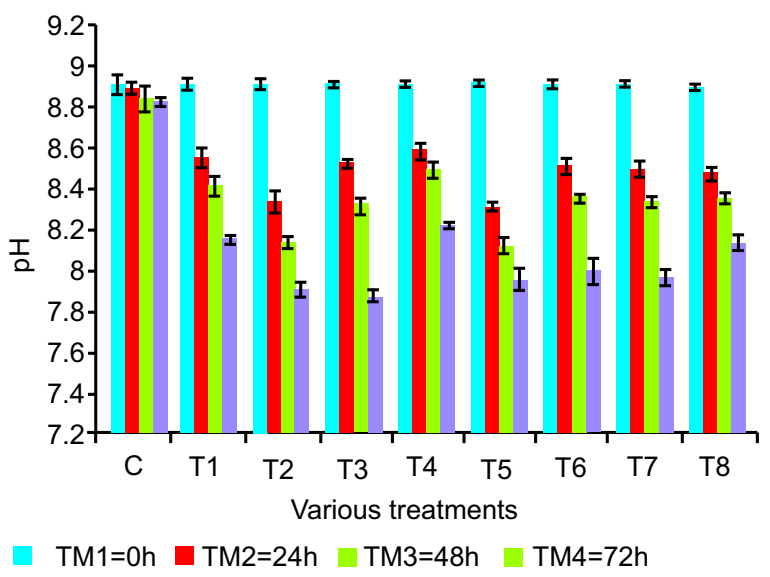

Fig. 3. Effect of various treatments for different retention times (TM) on $\mathrm{pH}$ value of reactive blue dye enriched textile water. for this combination of plant and bacteria after maximum hydraulic retention time (Fig. 4). Hence the combine effect of plant and bacteria significantly reduced the EC value of blue dye enriched solution with increasing retention time.

This reduction in EC has been acknowledged due to decrease in soluble salts that might have been taken by plants (Seenivasan et al., 2015) and bacterial addition has been reported to enhance this factor by promoting plant growth resulting in adding up the nutrient up taking ability of the plants through their roots and shoots (Ugya et al., 2015).

Effect of various treatments and hydraulic retention time on TDS value of reactive blue dye enriched textile water. All selected treatments and retention times affected significantly the TDS value of the blue dye enriched textile wastewater. Maximum value of TDS (5997 mg/L) was noted for control treatment (C) at start of the experiment $(\mathrm{TM} 1=0 \mathrm{~h})$ that reduced significantly to $2137 \mathrm{mg} / \mathrm{L}$ after $72 \mathrm{~h}$ when the water was treated with $E$. crassipes in partnership with $B$. cereus. There was found $64.37 \%$ reduction in TDS of wastewater under this combination of treatment after maximum retention time (Fig. 5). The results reflected that TDS value of the dye enriched textile water reduced significantly when it was treated with $E$. crassipes plant in partnership with $B$. cereus bacteria with increasing hydraulic retention time.

This substantial reduction in TDS of the effluents is attributed to plant-microbe interactive mechanisms

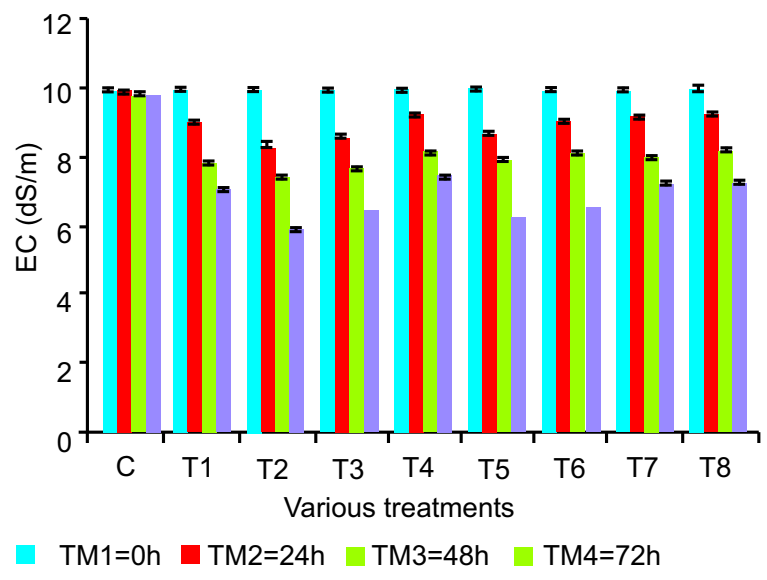

Fig. 4. Effect of various treatments for different retention times (TM) on EC value of reactive blue dye enriched textile water. 


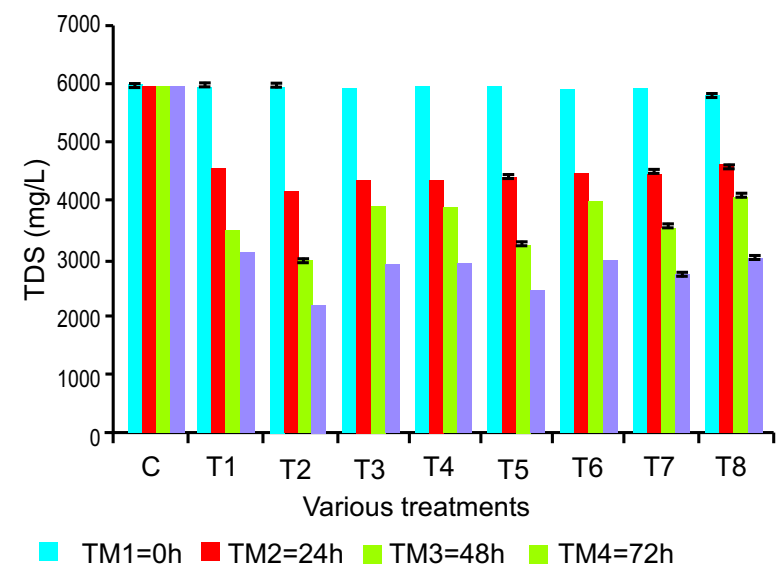

Fig. 5. Effect of various treatments for different retention times (TM) on TDS value of reactive blue dye enriched textile water.
(Abou-Elela et al., 2017) that improved pollutant degradation process of wetlands. According to this, plant's roots provide more spaces for bacteria attachment, settlement and trapping of suspended particles in the water. These spaces also motivate the adsorption and accommodation in plant tissues for both organic and inorganic matters, while the bacteria presence enhance the efficacy of these processes due to having ability to degrade, transform and mineralize the contaminants.

Effect of various treatments and hydraulic retention time on TSS value of reactive blue dye enriched textile water. TSS value of the wastewater was found to be affected significantly by all treatments and time selected for the present study. TSS value of the wastewater was maximum $(237 \mathrm{mg} / \mathrm{L})$ at start of the treatment $(\mathrm{TM} 1=$ $0 \mathrm{~h}$ ) for control reactor $(\mathrm{C})$. This value got maximum reduction $(58.23 \%)$ after $72 \mathrm{~h}$ retention time under combined treatment of plant and bacteria (E. crassipes and B. cereus) and after reducing up to $99 \mathrm{mg} / \mathrm{L}$ (Fig. 6). These outputs narrated a significant impact of both E. crassipes plant and $B$. cereus bacteria to reduce TSS value of the wastewater with increasing time.

This significant decrease in TSS value due this plantbacteria partnership might be credited towards the root structure of plants in this system that provides more sites for microbial attachment, filtering, settlement and trapping of suspended particles. Moreover the presence of plant growth promoting and pollutant degrading bacteria enhanced this factor by growing dense root

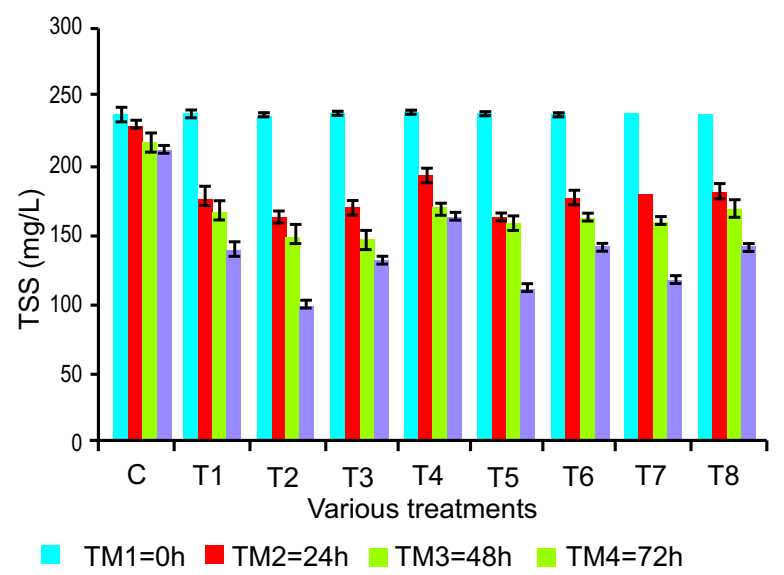

Fig. 6. Effect of various treatments for different retention times (TM) on TSS value of reactive blue dye enriched textile water.

system of plant along with degrading and mineralizing the pollutants (Hussein and scholz, 2018).

\section{Conclusion}

All pollutant indicating parameters like $\mathrm{pH}, \mathrm{EC}, \mathrm{TDS}$, TSS, of reactive blue dye enriched textile effluent were significantly decreased by the combined use of plants and microbes in floating treatment wetlands system. $E$. crassipes plant and B. cereus bacterial strain partnership $\left(\mathrm{T}_{2}\right)$ was found to be the most effective combination as compared to other selected treatment combinations for degradation of reactive blue dye enriched textile water. So, it can be concluded that E. crassipes plant in partnership with $B$. cereus bacteria may be a remarkable choice for treating reactive dye enriched textile wastewater. This plant is found in abundance in the surroundings of Faisalabad (the textile industry hub of Pakistan) showing its suitability in native climate of this city. Moreover, this study disclosed FTWs as an effective platform for plant-bacteria interaction to cleanse textile effluents in eco-friendly way. This study paved the path for in situ application of this technology to treat textile wastewater.

Conflict of Interest. The authors declare no conflict of interest.

\section{References}

Abou-Elela, S.E. M., Khlil, M., Hellal M, 2017. Factors affecting the performance of horizontal flow constructed treatment wetland vegetated with 
Cyperus papyrus for municipal wastewater treatment. International Journal of Phytoremediation, 19: 1023-1028 .

Afzal, M., Shabir, G., Tahseen, R., Ejazul, I., Iqbal, S., Khan, Q.M., Khalid, Z.M. 2014. Endophytic Burkholderia sp. strain PsJN improves plant growth and phytoremediation of soil irrigated with textile effluent. Clean Soil Air Water, 42: 1304-1310.

Andrade, L.S., Ruotolo, L.A., Rocha-Filho, R.C., Bocchi, N., Biaggioand, S.R., Iniesta, J. 2007. On the performance of $\mathrm{Fe}$ and $\mathrm{Fe}, \mathrm{F}$ doped $\mathrm{Ti}-\mathrm{Pt} / \mathrm{PbO}_{2}$ electrodes in the electro-oxidation of the blue reactive 19 dye in simulated textile wastewater, Chemosphere, 66: 2035-2043.

Anuprita, D.W., Khandare, R.V., Waghmare, P.R., Jagadale, A.D., Govindwar, S.P., Jadhay, J.P. 2015. Treatment of textile effluent in a developed phytoreactor with immobilized bacterial augmentation and subsequent toxicity studies on Etheostomaolmstedi fish. Journal of Hazardous Material, 283: 698-704.

APHA. 2005. Standard Methods for the Examination of Water and Wastewater. $20^{\text {th }}$ edition, American Public Health Association, Washington, DC, USA.

Arshad, A., Ali, S., Nasir, S.K., Riaz, M., Arshad, S., Arslan, Ch., Noor, S., Waqas, M.M. 2017. Design of floating wetland for treatment of municipal wastewater and environmental assessment using emergy technique. Proceeding of International Academy of Ecology and Environmental Sciences, 7: 78-89.

Asghar, H.N., Rafique, H.M., Khan, M.Y., Zahir, Z.A. 2017. Phyto-remediation of light crude oil by maize (Zea mays L.) bio-augmented with plant growth promoting bacteria. Soil and Sediment Contamination, 26: 749-763.

Aslam, M.M., Hassan, I., Malik, M., Matin, A. 2004. Removal of copper from industrial effluent by adsorption with economical viable material, Electronic Journal of Environmental, Agricultural and Food Chemistry, 3: 658-664.

Ayed, L., Bakir, K., Achour, S., Cheref, A., Bakhrouf, A. 2017b. Exploring bio-augmentation strategies for azo dye CI reactive violet 5 decolourization using bacterial mixture: dye response surface methodology, Water and Environmental Journal, 3: 80-89.

Ayed, L., Bakir, K., Mansour, H.B., Hammami, S., Cheref, A., Bakhrouf, A. 2017a. In vitro mutagenicity, NMR metabolite characterization of azo and triphenyl methanes dyes by adherents bacteria and the role of the "can" adhesion gene in activated sludge, Microbial Pathogenesis, 103: 29-39.

Bedekar, P.A., Saratale, R.G., Saratale, G.D., Govindwar, S.P. 2014. Oxidative stress response in dye degrading bacterium Lysinibacillus sp. RGS exposed to reactive orange 16, degradation of RO16 and evaluation of toxicity. Environmental Science and Pollution Res, 21: 11075-11085.

Chang, J.S., Chou, C., Lin, Y.C., Lin, P.J., Ho, J.Y., Hu T.L. 2001. Kinetic characteristics of bacterial azodye decolorization by Pseudomonas luteola. Water Research, 35: 2841-2850.

Chang, N.B., Xuan, Z., Marimon, Z., Islam, K., Wanielista, M.P. 2013. Exploring hydro-biogeochemical processes of floating treatment wetlands in a subtropical storm water wet detention pond. Ecological Engineering, 54: 66-76.

Chen, T.Y., Kao, C.M., Hong, A., Lin, C.E., Liang, S.H. 2009. Application of ozone on the decolorization of reactive dyes orange-13 and blue-19. Desalination, 249: 1238-1242.

Choo, T.P., Lee, C.K., Low, K.S., Hishamuddin, O. 2006. Accumulation of chromium (VI) from aqueous solutions using water lities (Nymphaeaspontanea), Chemosphere, 62: 961-967.

Clark, V. 2004. SAS/STAT 9.1; User's Guide, North Carolina: SAS Institute Inc., Cary, NC, USA.

Hussein, A., Scholz, M., 2018. Treatment of artificial wastewater containing two azo textile dyes by vertical-flow constructed wetlands. Environmental Science and Pollution Research, 25: 6870-6889.

Hwang, L., LePage, B.A. 2011. Floating Islandsan alternative to Urban Wetlands. In: Wetlands, LePage, B. (eds), pp. 237-250, Springer, Dordrecht.

Kabra, A.N., Khandare, R.V., Govindwar, S.P. 2013. Development of a bioreactor for remediation of textile effiuent and dye mixture: A plant bacterial synergistic strategy, Water Research, 47: 1035-1048.

Kalyani, D.C., Telke, A.A., Dhanve, R.S., Jadhav, J.P., 2009. Eco-friendly bio-degradation and detoxification of reactive red 2 textile dye by newly isolated Pseudomonas sp. SUK1. Journal of Hazardous Material, 163: 735-742.

Khandare, R., Kabra, A., Kadam, A., Govindwar, S. 2013. Treatment of dye containing wastewaters by a developed lab scale phytoreactor and enhancement of its efficacy by bacterial augmentation, International Journal of Biodeterioration and Biodegradation, 78: 89-97. 
Khandare, R.V., Govindwar, S.P. 2016. Microbial degradation mechanism of textile dye and its metabolic pathway for environmental safety. Environmental Waste Management, Ch. 14: 399439.

Li, S., Lissner, J., Mendelssohn, I. A., Brix, H., Lorezen, B., McKee, K.L., Mio, S. 2010. Nutrient and growth responses of cattail (Typha domingensis) to redox intensity and phosphate availability. Annals of Botany, 105: 176-184.

Lynch, J., Fox, L.J., Owen, J.S., Sample, D.J. 2015. Evaluation of commercial floating Treatment wetland technologies for nutrient remediation of storm water. Ecological Engineering, 75: 6169.

Maqbool, Z., Hussain, S., Ahmad, T., Nadeem, H., Imran, M., Khalid, A., Abid, M., Martin-Laurent, F. 2016. Use of RSM modeling for optimizing decolorization of simulated textile wastewater by Pseudomonas aeruginosa strain ZM130 capable of simultaneous removal of reactive dyes and hexavalent chromium. Environmental Science and Pollution Research; 23: 11224-11239.

Mishra, S., Maiti, A., 2018. The efficacy of bacterial species to decolourise reactive azo, anthroquinone and triphenylmethane dyes from wastewater: a review, Environmental Science and Pollution Research, 25: 8286-8314.

MohdSalleh, M.A., Mahmoud, K., Abdul-Karim, A.A., Idris, A. 2011. Cationic and anionic dye adsorption by agricultural solid wastes: A comprehensive review, Desalination, 280: 1-13.

Nair, S.S., Swarnalatha, K.D. 2015. Bio-degradation of laundry wastewater. International Research Journal of Engineering and Technology, 2: 789-793.

Ozturk, E., Karaboyici, M., Yetis, U., Yigit, N., Kitis, M. 2015. Evaluation of integrated pollution prevention control in a textile fibre production and dyeing mill, Journal of Cleaner Production, 88: 116-124.

Patil, P.S., Phugare, S.S., Jadhav, S.B., Jadhav, J.P. 2010. Communal action of microbial cultures for Red HE3B degradation, Journal of Hazardous Materials, 181: 263-270.

Pawan, K., Kumar, N., Kumar, M. 2015. Phytoremediation of waste water through aquatic plants for the change detection analysis in the chemical properties within the ditrict dhanbad, Jharkhand. International Journal of Research in Engineering and Technology, 2: 243-252.
Prasad, S.S., Aikat, K. 2014. Study of bio-degradation and bio-decolourization of azo dye by Enterobacter sp. SXCR, Environmental Technology, 35: 956965.

Rafique, H.M. 2015. Bio-remediation of Petroleum Hydrocarbon Contaminated Soil in Association with Plant, PhD Thesis, Institute of Soil and Environmental Sciences, University of Agriculture. Faisalabad. Pakistan.

Saha, P., Shinde, O., Sarkar, S. 2017. Phyto-remediation of industrial mines wastewater using water hyacinth. International Journal of Phytoremediation, 19: 87-96.

Sala, M., Gutierrez-Bouzan, M.C. 2012. Electrochemical techniques in textile processes and wastewater treatment: a review, International Journal of Photoenergy, 2012: 1-12.

Seenivasan, R., Prasath, V., Mohanraj, R. 2015. Restoration of sodic soils involving chemical and biologicalamendments and phyto-remediation by Eucalyptus camaldulensis in a semiarid region. Environmental Geochemistry and Health, 37: 575586.

Shah, M.P. 2014. An application of bio-augmentation strategy to decolourize \& degrade reactive black dye by Pseudomonas spp. International Journal of Environmental Bioremediation and Biodegradation, 2: 50-54.

Shehzadi, M., Afzal, M., Khan, M.U., Islam, E., Mobin, A., Anwar, S., Khan, Q.M. 2014. Enhanced degradation of textile effluent in constructed wetland system using Typha domingensis and textile effluent-degrading endophytic bacteria. Water Research, 58: 152-159.

Somasiri, W., Li, X.-F., Ruan, W-Q., Jian, C. 2008. Evaluation of the efficacy of upflow anaerobic sludge blanket reactorin removal of colour and reduction of COD in real textile wastewater. Bioresource Technology, 99: 3692-3699.

Song, S., Yao, J., Zhiqiao, H., Jianping, Q., Jianmeng, C. 2008. Effect of operational parameters on the de-colourization of C.I. reactive blue 19 in aqueous solution by ozone-enhanced electro-coagulation, Journal of Hazardous Materials, 152: 204-210.

Sudha, M., Saranya, A., Selvakumar, G., Sivakumar, N. 2014. Microbial degradation of azo dyes: a review, International Journal of Current Microbiology and Applied Sciences, 3: 670-690.

Ugya, Y.A., Tahir, S.M., Imam, T.S. 2015. The Efficiency of Pistia Stratiotes in the phyto-remediation of 
romi stream: a case study of Kaduna refinery and petrochemical company polluted stream. International Journal of Health Sciences and Research, 5: 494-497.

Valaria, T., Giansanti, P., Mangiavillano, A., Pannocchia, A., Varesemm, G.C. 2011. Evaluation of toxicity, genotoxicity and enviornametal risk of simulated teaxtile and tannery waste waters with a battery of biotests, Ecotoxicology and Enviornamental Safety, 74: 866-874.

Vymazal, J. 2011. Constructed wetlands for wastewater treatment: five decades of experience. Environmental
Science and Technology, 45: 61-69.

Wang, N., Chu, Y., Wu, F., Zhao, Z., Xu, X. 2017. Decolorization and degradation of Congo red by a newly isolated white rot fungus, Ceriporialacerata, from decayed mulberry branches, International Journal of Biodeterioration and Biodegradation, 117: 236-244.

Zaidi, S., Usmani, S., Sing, B.R., Musarrat, J. 2006. Significance of Bacillus subtilis strain SJ-101 as a bioinoculant for concurrent plant growth promotion and nickel accumulation in Brassica juncea. Chemosphere, 64: 991-997. 